\title{
Comentário a \\ “Evento OU ATO? SOBRE AS CRÍticas de Ž̇ŽEK A BADIOU”
}

Fabiano Veliq ${ }^{1}$

Referência do artigo comentado: FISCHER, M. P. Evento ou ato? Sobre as críticas de Žižek a Badiou. Trans/Form/Açáo: revista de filosofia da Unesp, v. 44, n. 3, p. 317-336, 2021.

O texto intitulado "Evento ou Ato? Sobre as críticas de Žižek a Badiou”, de Mariana Pimentel Fischer (2021), traz um tema importantíssimo para o debate contemporâneo, a partir de dois filósofos cuja matriz de pertencimento é similar, a saber, o pensamento marxista e o pensamento lacaniano. Dessa forma, resgatar essa matriz e apontar as diferenças entre os pensamentos desses autores coopera muito com uma sistematização do pensamento, para quem deseja iniciar as investigaçóes a respeito da filosofia política e o seu diálogo com a Psicanálise.

Fischer (2021) aborda com profundidade o conceito de ato e o conceito de evento, e evidencia como Badiou e Žižek lidam com o tema, de forma que é possível remeter tal debate não apenas a uma questão terminológica, mas a uma questáo ontológica de fundo.

Para Badiou, como bem exposto por Fischer (2021), o sujeito não poderia ser pensado somente como algo que pertence à ordem daquilo

${ }^{1}$ Doutor em Psicanálise pela PUC Minas e doutorando em Filosofia pela UFMG. Professor Adjunto I do Departamento de Filosofia da PUC Minas, Belo Horizonte, MG - Brasil. (D) https://orcid. org/0000-0001-6273-1333 E-mail: veliqs@gmail.com

https://doi.org/10.1590/0101-3173.2021.v44n3.26.p337 
que é contado como ponto vazio "0", mas extravasaria a própria estrutura. A proposta de Badiou terá como ponto de partida, nessa nova fase do seu pensamento, a Matemática pensada enquanto ontologia possível.

Em seu livro Ser e Evento (1996), Badiou desenvolverá essas noçôes de maneira mais pormenorizada, tendo em vista as teorias sobre o infinito de Cantor e procurando reler a história da filosofia, a partir da noçáo de multiplicidade. A ontologia seria igualada à Matemática como única forma possível de pensar a estrutura do mundo. Nisto consistiria a ruptura ontológica proposta por Badiou: o Um surge apenas depois do Zero e das multiplicidades. O Zero seria a multiplicidade sem os Uns, que garantiria a consistência ontológica delas. Disso deriva, no pensamento de Badiou, que a realidade é uma multiplicidade na qual o vazio e o múltiplo coincidem.

É, portanto, a partir dessa nova ontologia de fundo que o evento será encarado. $\mathrm{O}$ evento seria aquilo que está de alguma forma ligado à estrutura, contudo, não é contado como pertencente à estrutura, mas se constitui como algo que irrompe da situação, fruto de um instante, uma decisão, algo que escapa à verdade da situaçáo, e é posteriormente nomeado por um sujeito que adere ao evento. Assim como Paulo, no início do Cristianismo, ou Lenin com a Revolução Russa. É a interpretação do sujeito que percebe que uma mudança substancial ocorreu que atesta a verdade envolvida no evento.

Para o filósofo esloveno Slavoj Žižek, a questão levantada por Lacan, e em certa medida por Badiou, aponta para uma espécie de incompletude ontológica da própria realidade, que teria na física quântica o seu modelo de como pensar uma ontologia aberta, e a filosofia de Alain Badiou e sua noção de multiplicidade pura como categoria ontológica definitiva: a realidade seria a multiplicidade das multiplicidades que não pode ser gerada ou constituída a partir de uma forma de Uns como seus constituintes elementares. As multiplicidades não são multiplicaçôes de Um, mas multiplicidades irredutíveis, sendo, por isso, que o seu oposto não seria o Um, mas Zero, ou seja, o vazio ontológico.

Com base na noção do mundo ancorado sobre o vazio proposto por Badiou, Žižek é capaz de defender a ideia que ele assume de materialismo, a qual nada teria a ver com a presença da matéria úmida e densa, mas teria a ver exatamente com a noção de que a Totalidade é Nada. Assinala Žižek: 
O materialismo não é a asserção da densidade material inerte em seu peso úmido - tal "materialismo" pode sempre servir de apoio para o obscurantismo espiritualismo gnóstico. Em contrapartida, o verdadeiro materialismo assume com alegria o "desaparecimento da matéria", o fato de existir apenas o vazio. (ŽIŽEK, 2014 p. 129).

É em seu livro O sujeito incômodo que Žižek debaterá com a teoria do Evento-Verdade de Badiou e também com a leitura do livro de Badiou sobre São Paulo. Nesse livro, Žižek está partindo da noção de "Acontecimento" proposta por Alain Badiou, em seu livro Ser e evento (1996), no qual Badiou evidenciará que o acontecimento é algo não previsto na ordem das coisas, inserindo em sua dinâmica um ponto de inflexão da ordem vigente; nesse sentido, o acontecimento muda o caminhar dos fatos e permite um novo momento no mundo. O acontecimento é o Real impossível de uma estrutura, de sua ordem simbólica sincrônica, o gesto gerador violento que ocasiona a Ordem legal que retroativamente torna ilegal esse mesmo gesto, relegando-o ao status espectral reprimido de algo que jamais pode ser totalmente reconhecidosimbolizado-confessado.

Em suma, a ordem estrutural sincrônica é um tipo de formador de defesa contra seu acontecimento fundador, o qual só pode ser discernido na forma de uma narrativa mítica espectral. Ou seja, a estrutura só pode funcionar mediante a ocultação da violência do seu acontecimento fundador. Žižek (2013 p. 34) ressalta:

O evento badiouiano é uma ruptura na ordem do ser (realidade fenomenal constituída transcendentalmente), a intrusão de uma ordem ("numenal") radicalmente heterogênea, de modo que estamos claramente em um espaço (pós)-kantiano. É por isso que podemos definir a filosofia sistemática de Badiou como um kantismo reinventado para a época da contingência radical: em vez de uma realidade constituída transcendentalmente, temos uma multiplicidade de mundos, cada um delineado por sua matriz transcendental, uma multiplicidade que não pode ser mediada/unificada em um único enquadramento transcendental mais amplo; em vez de uma lei moral, temos a fidelidade ao Verdade-Evento que é sempre específico com respeito a uma situaçáo particular de um Mundo.

O texto de Fischer traz especial ênfase à leitura de Badiou e Žižek a respeito da figura de São Paulo (leitura esta também feita por Lacan, no seu Seminário VII) e, com ela, a leitura da noção de ressurreição proposta 
por ele. Como bem mostrou Fischer, aqui as leituras divergem bruscamente. Para Badiou, a ressurreição é vista por Paulo como um evento fundador de uma nova verdade que se estabelece e reconfigura o mundo, de sorte que a fidelidade ao evento da ressurreição observada por Paulo é capaz de inaugurar algo novo para o mundo.

De acordo com Žižek, a morte e a ressurreição seriam a mesma coisa, e a morte do Cristo apontaria não para um evento fundador de algo novo, mas o Cristianismo mostraria Deus como apenas mais um humano, como homem miserável indiscernível de outros humanos, no que diz respeito às suas propriedades intrínsecas. Argumenta Žižek (2012 p. 190):

Com a aparição de Cristo isso representa efetivamente a morte de Deus: Fica claro que Deus não é senáo o excesso do homem, o "demais" de vida que não pode ser contido em qualquer forma de vida, que viola a forma (morphé) do antropomorfismo.

Na morte de Deus, portanto, o que se revela já é a sua ressurreição enquanto conteúdo verdadeiro e absoluto. A morte de Deus é entendida como sendo não apenas o momento da negação, todavia, ao mesmo tempo, o momento da negação da negação em um movimento simultâneo. A morte de Deus seria o fim e a sua ressurreição se daria apenas como um ato de fé da comunidade. Longe, portanto, de ser um "evento fundador", como quer Badiou, a morte e a ressurreição seriam encaradas como a entrada do mundo em um momento no qual a morte de Deus deixa um vazio e abre a possibilidade para um novo materialismo, pautado por aquilo que Žižek nomeará, em outros trabalhos, como "menos que nada", i.e, uma aposta ontológica no vazio que tem no Cristianismo o início para um ateísmo de fato materialista.

\section{REFERÊNCIAS}

BADIOU, Alain; BORGES, Maria Luíza Xavier de Almeida. O ser e o evento. Rio de Janeiro: Jorge Zahar: Ed. UFRJ, 1996.

FISCHER, Mariana P. Evento ou ato? Sobre as críticas de Žižek a Badiou. Trans/Form/ Açáo: revista de filosofia da Unesp, vol. 44, n. 3, p. 317-336, 2021.

LACAN, Jacques. O seminário. Livro 7: A ética da psicanálise; 1959-1960. Texto estabelecido por Jacques-Alain Miller; [versão brasileira de Antônio Quinet]. Rio de Janeiro: Jorge Zahar, 2008 (Campo freudiano no Brasil). 
ŽIŽEK, Slavoj. O amor impiedoso [ou: sobre a crença]. Tradução de Lucas Melo Carvalho Ribeiro. Belo Horizonte: Autêntica, 2012.

ŽIŽEK, Slavoj. Menos que nada. Hegel e a sombra do materialismo dialético. Tradução de Rogério Bettoni. São Paulo: Boitempo, 2013.

ŽIŽEK, Slavoj; MILBANK, John. A monstruosidade de Cristo. São Paulo: Três Estrelas, 2014.

Recebido: $18 / 5 / 2021$

Aceito: 22/5/2021 
VELIQ, F. 